\title{
Effect of Leadership Styles on School Administration (A Case Study of Five Selected Secondary Scools in Bo City)
}

Stella B. Fortune

Lecturer, Education Department Eastern Polytechnic Kenema Eastern Province Republic of Sierra Leone

\section{Article History}

Received: 13.08 .2020

Accepted: 01.09.2020

Published: 14.11.2020

Journal homepage:

https://www.easpublisher.com/easjehl

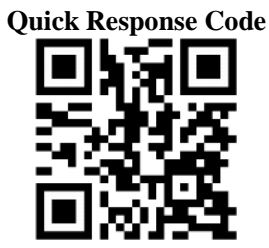

Abstract: The study was carried out in Bo City, Southern Province - Republic of Sierra Leone. Bo city is the third largest city in Sierra Leone by population (after Freetown and Kenema) and the largest city in the Southern Province. Bo is the capital and administrative centre of the District. Bo is an urban centre and lies approximately 160 miles $(250 \mathrm{~km})$ east south-east of Freetown and about 44 miles to Kenema. Bo is the leading financial, educational and economic centre of Southern Sierra Leone. Bo was previously the second largest city in Sierra Leone by population, the city is the primary home of Njala University, the second largest university in Sierra Leone, after the Fourah Bay College. Bo is also home to the Bo Government Secondary School, commonly known as Bo School, which is one of the biggest and most prominent secondary schools in West Africa. The school has a history of producing some of Sierra Leone's most gifted and outstanding students. The study was initiated to investigate the Effect of Leadership Styles on School Administration in Selected Secondary Schools in Bo City. The study hypothesised that there is a relationship between administrators' leadership styles and school effectiveness for the smooth running of the school which enhances commitment of teachers towards quality education. Most important of what the study revealed was that, many teachers have been elevated to leadership positions (administrators) without much formal administrative training leading to ineffectiveness and mismanagement of schools, hence poor students' performance and disappointing results. It was also revealed that many schools that were once effective in academic performance have lowered their standards due to poor leadership while some have greatly improved through effective leadership. The effectiveness of schools has continued to dwindle despite the fact that the schools in the country are assumed to have adequate and well trained teachers, fairly good pupils from primary schools and some trained and qualified administrators. Notwithstanding, the reason for the ineffectiveness of schools cannot be easily discerned without focused investigation. The question is: could the poor performance of Junior Secondary schools be attributed to principals' leadership styles? Against this backdrop, the study is tailored to investigate 'The Effect of Leadership Styles on Administration" as a case study.

Keywords: Leadership, Styles, Administration.

Copyright $(\mathcal{C} 2020$ The Author(s): This is an open-access article distributed under the terms of the Creative Commons Attribution 4.0 International License (CC BY-NC 4.0) which permits unrestricted use, distribution, and reproduction in any medium for non-commercial use provided the original author and source are credited.

\section{INTRODUCTION}

Education today is a complex and expensive enterprise. In Sierra Leone, the system is growing fast. For these reasons, it is important to ensure that she educational system works with a maximum of efficiency and a minimum of wastes in its various aspects and functions. To ensure this, the educational system should be efficiently managed and monitored. Good educational administration is an "'eye opener" at least to some of the problems facing educational institutions. As such, good educational administration makes all important stakeholders in an educational system of a country to be aware of how and why certain decisions in education are taken or how one method of solving educational problems may be preferred to another.

Leadership styles can roughly be referred to as the behaviour of a leader through which he/she influences the followers Lutherns, 1989. Campbell 1986 observes that, what a leader chooses to do, when he /she does it, and the manner in which he /she acts constitutes his /her leadership style. Leadership style of school head plays an important role in effective school administration. According to Mukeredzi and Chireshe 2005 leadership styles have a bearing on the achievement of organizational goals. 
A leadership style is a set of leadership activities that influence subordinates or individuals to achieve organizational goals Leithwood and Jutzi, 1999. Some of the leadership styles used by school heads:

Be as it may, Leadership in administration deals with the patterns of behaviour school leaders/heads adopt to plan, organize, direct, supervise and evaluate all learning activities in educational institutions in order to achieve educational goals. Leadership styles are important because a school administrator's leadership style for example, has a direct influence of how the teachers feel and the extent to which the teachers are motivated to work efficiently.

Leadership is an important organizational variable and a key determinant of employee Performance. In addition, a leader should use different leadership styles in order to maximize positive effect in different contexts Gibbs, Knapper, \&Piccinin, 2008. As Gibbs, Knapper, and Piccinin 2008 noted, educational leaders must negotiate a variety of factors related to

culture, geographical location, and subject. The quality of leadership affects the classroom learning climate, student discipline, and cooperation of their guardians, among other issues Kolak, 2010. Against this backdrop, it is important to investigate the effect of leadership style on school administration.

\section{RESEARCH OBJECTIVES}

The topic under investigation is tailored to:

1. Investigate whether principals in targeted schools are trained and qualified administrators.

2. Assess the kind of leadership style(s) that are practiced by administrators in targeted schools

3. Examine the impact of leadership styles practiced by administrators on targeted schools.

4. Proffer recommendations and strategies that would improve school administration and leadership styles to enhance school effectiveness.

\section{Methodology}

This research work was done in five randomly selected junior secondary schools in Bo City, Southern
Province, Republic of Sierra Leone. The study adopted a case study to explore the effect of Leadership styles on School Administration. The study sample comprised of two administrators and ten teachers from each targeted school. Making a total of twelve participants per school, (ten administrators and fifty teachers) which gives a total of sixty participants covering all the five selected schools in the study area.

The major instruments used to collect data for this study were questionnaires and personal interviews. The questionnaires were excusive enough to address the objectives of the study.

Data collected from participants were analysed in both qualitative and quantitative modes. The quantitative data was analysed in tables while the quantitative was analysed in narrative forms

\section{RESUlTS AND DisCuSSIONS}

This section presents the analysis of data which covers a total of five selected junior secondary schools in Bo City. The research took the following into consideration; whether principals in targeted schools are trained and qualified administrators; the kind of leadership style(s) that are practiced by administrators in targeted schools; the impact of leadership styles practiced by administrators on targeted schools; recommendations and strategies that would improve school administration and leadership styles to enhance school effectiveness.

A list of tables has been used to address a number of questions. Below are the data collected from targeted participants of the study.

- The profile of the respondents

- Whether principals in targeted schools are trained and qualified school administrators

- Identification of the kind of leadership styles adopted by principals

- The impact of leadership styles practiced by administrators on targeted schools

- Recommendations and strategies that would improve school administration and management to enhance school effectiveness.

Table-1: Profile of respondents according to sex

\begin{tabular}{|l|l|l|}
\hline Sex & Absolute Frequency (AF) & Relative Frequency (RF\%) \\
\hline Male & 44 & $72.3 \%$ \\
\hline Female & 16 & $27.7 \%$ \\
\hline Total & $\mathbf{6 0}$ & $\mathbf{1 0 0 \%}$ \\
\hline
\end{tabular}

The table above revealed the sex categories of the respondents contacted, $44(72.3 \%)$ of them were males and 16(27.7\%) were females. The data indicated that there are more male administrators than female administrators in the study area. 
Table-2: Age distribution of respondents

\begin{tabular}{|l|l|l|}
\hline Age & Absolute Frequency $(\mathbf{A F})$ & Relative Frequency $(\mathbf{R F} \%)$ \\
\hline 18-28 years & 21 & 35 \\
\hline 29-39 years & 34 & 56.7 \\
\hline 40-50 years & 04 & 6.7 \\
\hline 51-60 years & 01 & 1.6 \\
\hline Above 61 years & - & - \\
\hline Total & $\mathbf{6 0}$ & $\mathbf{1 0 0 \%}$ \\
\hline
\end{tabular}

$\mathrm{N}=60$

Table 2 above shows that, $34(56.7 \%)$ of the respondents were within the age bracket of 29-39years, $21(35 \%)$ were within the age bracket of 18- 28 years, $4(6.7 \%)$ were within $40-50$ years $1(1.6 \%)$ within $51-60$ years and above 61 years no respond. However the result showed that majority of the respondents were young people.

Table-3: Marital status of respondents

\begin{tabular}{|l|l|l|}
\hline Marital status & Absolute Frequency (AF) & Relative Frequency (RF\%) \\
\hline Single & 36 & $60 \%$ \\
\hline Married & 24 & $40 \%$ \\
\hline Divorced & - & - \\
\hline Others specify & - & - \\
\hline Total & $\mathbf{6 0}$ & $\mathbf{1 0 0 \%}$ \\
\hline \multicolumn{2}{|l}{} \\
\hline
\end{tabular}

According to table 3 above, among the targeted respondents $36(60 \%)$ of them are single and
$24(40 \%)$ are married. This implies that more than half of the respondents were unmarried.

Table-4: Qualification of respondents

\begin{tabular}{|l|l|l|}
\hline Qualification & Absolute Frequency (AF) & Relative Frequency (RF\%) \\
\hline Teachers Certificate & 5 & $8.3 \%$ \\
\hline $\begin{array}{l}\text { Higher eachers Certificate } \\
\text { (Secondary) }\end{array}$ & 38 & $63.3 \%$ \\
\hline $1^{\text {st }}$ Degree & 11 & $18.3 \%$ \\
\hline $2^{\text {nd }}$ Degree & 6 & $10.1 \%$ \\
\hline Others (specify) & - & - \\
\hline Total & $\mathbf{6 0} \quad \mathbf{N}=60$ & $\mathbf{1 0 0 \%}$ \\
\hline
\end{tabular}

Table 4 above shows that $38(63.3 \%)$ of the respondents were holders of Higher Teachers' certificates, indicating that they are trained and qualified teachers. $11(18.3 \%)$ were first degree holders and $6(10 \%)$, second degree holders while 5(8.3\%) were holders of Higher National Diploma Certificates. Therefore, all of the respondents are trained and qualified to teach in secondary schools.

Table-5: Teaching experience of respondents

\begin{tabular}{|l|l|l|}
\hline \multicolumn{1}{|c|}{ Teaching experience } & Absolute Frequency (AF) & Relative Frequency (RF\%) \\
\hline Below 1 year & 6 & $10 \%$ \\
\hline 1-5 years & 19 & $31.7 \%$ \\
\hline 6-10 years & 31 & $51.7 \%$ \\
\hline 11-15 years & 1 & $1.6 \%$ \\
\hline Above 15 years & 3 & $5 \%$ \\
\hline Total & $\mathbf{6 0}$ & $\mathbf{1 0 0 \%}$ \\
\hline
\end{tabular}

Table 5 above divulged that, $31(51.7 \%)$ of the respondents have experience about $6-10$ years, 19 $(31.7 \%) 1-5$ years, $6(10 \%)$ below a year and $3(5 \%)$ of the targeted population said they have teaching experience above 15 years. However, majority of the respondents have quality teaching experienced as teachers. 
Table-6: Knowledge on what leadership is

\begin{tabular}{|l|l|l|}
\hline Definition of leadership & Absolute Frequency (AF) & Relative Frequency (RF\%) \\
\hline A person that leads while others follow & 21 & $35 \%$ \\
\hline A person that rules only to satisfy his/her leadership & 4 & $5 \%$ \\
\hline $\begin{array}{l}\text { A person that leads to influence the behavior of others } \\
\text { to achieve set goal(s) }\end{array}$ & 36 & $60 \%$ \\
\hline $\begin{array}{l}\text { A person that is appointed to head an organization and } \\
\text { the satisfaction of only his/her management }\end{array}$ & - & - \\
\hline A person that forces his way into authority & - & - \\
\hline Total & $\mathbf{6 0}$ & $\mathbf{1 0 0 \%}$ \\
\hline
\end{tabular}

Table 9 indicates that, $36(60 \%)$ of the respondents viewed leadership as a person that leads to influence the behaviour of others to achieve set goal (s), $21(36 \%)$ said leaders are People who lead others, 3(5\%) said a leader is a person that rules only to satisfy his/her leadership. Therefore, majority of the respondent have knowledge on what leadership is.

Table-7: Wether ptincipals are trained and qualified administrators

\begin{tabular}{|l|l|l|}
\hline Trained and untrained administrators & Absolute Frequency (AF) & Relative Frequency (RF\%) \\
\hline Trained & 6 & $60 \%$ \\
\hline Untrained & 4 & $40 \%$ \\
\hline Total & $\mathbf{1 0}$ & $\mathbf{1 0 0 \%}$ \\
\hline
\end{tabular}

According to the data obtained in table 7, 46 (76.7\%) of the respondents agreed that their principals are trained in school administration and management, and $14(24.3 \%)$ of the targeted respondents said their administrators are not trained in school administration.
This indicates that, those administrators who are not trained and qualified in administration might be having difficulty in administering their schools towards school effectiveness.. Thus knowledge of a process makes a difference.

Table-8: Kind(s) of leadership style(s) practiced by school administrators

\begin{tabular}{|l|l|l|}
\hline Leadership style & Absolute Frequency (AF) & Relative Frequency (RF\%) \\
\hline Democratic leadership style & 11 & $18.3 \%$ \\
\hline Authoritarian leadership style & 13 & $21.7 \%$ \\
\hline Affiliative leadership style & 3 & $5 \%$ \\
\hline Lassez- faire leadership style & - & - \\
\hline Participative leadership style & 13 & $21.7 \%$ \\
\hline coaching leadership style & 9 & $15 \%$ \\
\hline Others (specify) & 11 & $18.3 \%$ \\
\hline Total & $\mathbf{6 0}$ & $\mathbf{1 0 0 \%}$ \\
\hline
\end{tabular}

According to respondents on the kind of leadership style(s) practiced by school administrators, $13(21.7 \%)$ being the highest number of the administrators adopt authoritarian and participative leadership styles respectively. Administrators who fall in the authoritarian category gives directives rather than directions by telling staff what to do; does not listen to or permit much staff input; controls tightly through closed monitoring and expects immediate staff compliance or obedience. This type of leadership style may have negative effect if not used well. Such negative effects could be passive resistance, rebellion or even urging some staff members to leave the school. In the same vain, it can be effective when applied to relatively straight forward tasks; in crisis situations when staffs need clear direction and the administrator has more information than the staff; effective with staff members who do not perform well and other warnings have failed.

Participative leadership style which also ranked $13(21.7 \%)$, encourages supportive supervision; provides on-going advice and feedback; encourages staff members to establish long range goals of development. Participating leadership is most effective when there are staff members who are motivated to do new things or looking for ways to develop themselves professionally.

It is therefore opined that the above leadership styles can induce school effectiveness which enhances quality education. $11(18.7 \%)$ being the second highst is democratic leadership style which sometimes can be good according to the nature of the staffs, while 9 
$(15 \%)$ of the respondents said their heads adopt cooperative leadership style and $3(5 \%)$ indicated bureaucratic leadership style. This implies that $1 / 4$ of the respondents in the study area practice authoritarian and participative leadership styles.

Table-9: Impact of leadership styles practiced by administrators on targeted schools

\begin{tabular}{|l|l|l|}
\hline Impact of leadership styles & Absolute Frequency (AF) & Relative Frequency (RF\%) \\
\hline Participate in all activities & 5 & $8.3 \%$ \\
\hline Collect work & 29 & $48.3 \%$ \\
\hline Delegate responsibilities to subordinates & 8 & $13.3 \%$ \\
\hline Follow strict rules and regulations & 12 & $20 \%$ \\
\hline Spur teachers for effectiveness and efficiency & 1 & $1.7 \%$ \\
\hline $\begin{array}{l}\text { Consult others but does not include their view in the } \\
\text { final decision making }\end{array}$ & 1 & $1.7 \%$ \\
\hline Ability to solve unexpected problem & 1 & $1.7 \%$ \\
\hline Does not allow suggestions from staffs & 1 & $1.7 \%$ \\
\hline No response & 2 & $3.3 \%$ \\
\hline Total & $\mathbf{6 0}$ & $\mathbf{1 0 0 \%}$ \\
\hline
\end{tabular}

The data in table 9 revealed that, $29(48.3 \%)$ of the respondents school heads in the study area practice participative leadership styles, $12(20 \%)$ bureaucratic leadership style, 8 (13.3\% democratic leadership styles,
$5(8.3 \%)$ cooperative leadership styles, $2(3.3 \%)$ said no respond and $1(1.7 \%)$ motivate, benevolent, situational and authoritarian leadership styles.

Table-10: Possible recommendations to improve school management

\begin{tabular}{|l|l|l|}
\hline Possible recommendations for effective school management & $\begin{array}{l}\text { Absolute } \\
\text { Frequency } \\
\text { (AF) }\end{array}$ & $\begin{array}{l}\text { Relative } \\
\text { Frequency } \\
\text { (RF\%) }\end{array}$ \\
\hline $\begin{array}{l}\text { Set up committees within the school and embark on good community } \\
\text { relationship }\end{array}$ & 7 & 11.67 \\
\hline Proper record keeping, frequent leadership training and delegation of duties & 9 & $15 \%$ \\
\hline $\begin{array}{l}\text { Establish academic school clubs, organize competitions and encourage team } \\
\text { work }\end{array}$ & 3 & $5 \%$ \\
\hline Establish welfare department & 2 & $3.33 \%$ \\
\hline Proper monitoring, planning, organizing and coordinating & $20 \%$ \\
\hline $\begin{array}{l}\text { Effective and efficient communication across institutions and establish } \\
\text { guidance counseling department }\end{array}$ & 9 & $20 \%$ \\
\hline Heads should serve as good role model and encourage mentorship & 9 & $6.67 \%$ \\
\hline $\begin{array}{l}\text { Stimulate interest and create effective participation among staff in solving } \\
\text { problem }\end{array}$ & 4 & $6.67 \%$ \\
\hline Upgrade volunteer teachers and make education policies available to them & 4 & $6.67 \%$ \\
\hline Prompt payment of salaries & 1 & $1.67 \%$ \\
\hline Eliminate corrupt practices & 2 & $3.33 \%$ \\
\hline No respond & 6 & $10 \%$ \\
\hline Total & $\mathbf{6 0}$ & $\mathbf{1 0 0 \%}$ \\
\hline
\end{tabular}

In table $10,8(20 \%)$ of the targeted respondents espoused that for an effective system the school management should effectively efficiently communicate across the institution and establish guidance and counselling department, and proper monitory, planning, organizing, and coordinating, 9 $(15 \%)$ proper record keeping, frequent training and delegation of duties, 7 (11.62\%) set up committee within the school and embark on good community relationship, 6 (10\%) no respond, 4 (6.67\%)up- grated volunteer teachers and make educational institution available to them, $3(6.67 \%)$ stimulate interest and create effective participate among staff in solve problem, 2(5\%) establish academic club in the school, 2 $(3.33 \%)$ eliminate corruption, establish welfare department, serve as role model and $1(1.67 \%)$ prompt payment of salaries.

\section{Summary, Conclusion and Recommendations of Research Findings}

This part of the study constitutes the summary of the findings, conclusion and recommendations. 


\section{SUMMARY}

The summary of the findings according to the research conducted were as follows:

Males were nearly one third of the targeted respondents and majority were within the age bracket of 29-39 years. Therefore majority were young and energetic men which triggers to effective service delivery.

The study revealed that more than $50 \%$ of the targeted respondents were holders of certificates in teacher education and majority of respondents have attained tertiary education.

All of the respondents have experience in teaching and all of them are trained and qualified teachers. Among the administrators, $60 \%$ are trained and qualified as administrators while $40 \%$ are not qualified as school administrators since they are not trained.

The study findings indicated that the targeted respondents were having more than 6 years teaching experience and have served for about 5 years in their current institutions.

The results show that close to $50 \%$ of the respondents confirmed that a leader is a person that leads to influence the behaviour of others to achieve set goals.

$60 \%$ of the respondents agreed that their heads were trained in school administration and management. It was revealed that about $50 \%$ of the respondents rate their administrators as effective mangers of their schools. $58(9.7 \%)$ of the respondents affirmed that if a head is not trained in educational administration and management, this will negatively affect the smooth running of the school.

The study revealed that, $50 \%$ of the targeted respondents have served their administrators for two years and above. One third of the respondents agreed that their heads practiced authoritarian and participative leadership styles, while some said democratic, cooperative, bureaucratic leadership styles etc.

The study revealed that majority of the school heads adopt collective work which leads to school effectiveness. Also, 50\% of respondents believed that the leadership styles adopted by their heads are useful for school effectives, though $5(8.7 \%)$ believe that the leadership styles adopted by their administrators reduce school effectiveness.

The study revealed that, majority of the respondents agreed that combination of leadership styles lead to school effectiveness and $93.3 \%$ of the respondents agreed that their administrators are good role models to others. One third of the respondents affirmed that their administrators motivate them by appreciating what they have done by way of appraising them

The research revealed that, nearly half percent of the respondents believed that evaluation of self, teachers, pupils and the school as an institution is very good for school effectiveness.

Majority of the respondents revealed that their administrators monitor the school activities weekly. Therefore, monitoring is done by school heads for school effectiveness.

\section{CONCLUSION}

The study concluded that, there is a relationship between administrators' leadership styles and school effectiveness for the smooth running of the school which enhances commitment of teachers towards quality education.

Most important of what the study revealed was that, many teachers have been elevated to leadership positions (administrators) without much formal administrative training leading to ineffectiveness and mismanagement of schools, hence poor students' performance and disappointing results.

It was also revealed that many schools that were once effective in academic performance have lowered their standards due to poor leadership while some have greatly improved through effective leadership.

The effectiveness of schools has continued to dwindle despite the fact that the schools in the country are assumed to have adequate and well trained teachers, fairly good pupils from primary schools and some trained and qualified administrators.

Headship in schools should not be given to teachers who do have knowledge on educational administration and management.

School heads need to adopt different leadership styles to manage the welfare of schools. Motivation of all kinds is a tool to make the staff work extra to produce desirable results.

Setting up of committees to handle issues, establishes good relationship with the community, proper record keeping, encouraging mentorship and team work, in-service training and delegation of responsibilities make the system work effectively.

Participative and authoritarian leadership styles are very effective for school management, 
because it results to collective work and delegation of responsibilities.

\section{RECOMMENDATION(S)}

Having critically examined the whole exercise of the research work and its findings, the following recommendations are suggested:

- For effective school management, Government in collaboration witheducation officials should organize in-service training, seminars or workshop for teachers and administrators. Young people should be giving the opportunities to take leadership roles in schools.

- Government should add Educational Administration and Management in Senior Secondary School's curriculum, so that those who finish school and want to teach before going to college will have skills in managing and administering school.

- Principals should ensure that they set up committees to handle issues, establish good relationship with the community, proper record keeping, encourage mentorship and team work and delegate responsibilities for teachers to work effectively.
- The educational system must be efficiently managed and monitored by the Teaching Service Commission (TSC). Good educational administration is an "eye opener" at least to some of the problems facing educational institutions.

- Administrators must implement supportive supervision; provide on-going advice and feedback; encourage staff members to establish long range goals of development.

\section{REFFERENCE}

1. Better schools: resource materials for Heads in Africa

2. Franklin Atogiyire (Business Managemnet (Millennium Edition 5)

3. John, R. (2015). 5 core concepts of leadership

4. Micheal hughes \& Carolyn J. Kroehler- Sociology the Core ( 7 th edition)

5. Fortune, Stella, B. (2019). Lecture notes on Educational Administration and Management Eastern Polytechnic - Kenema, Sierra Leone

6. Warren Bennis (concept of leadership)

7. Willis, M. Watt. (2009). 10 recommendation towards effective leadership. 